\title{
Glucose-insulin relationships and thyroid status of cockerels selected for high or low residual food consumption
}

\author{
Jean-François Gabarrou*, Pierre Andre Geraert, John Williams, Laurent Ruffier and Nicole Rideau \\ Station de Recherches Avicoles, Institut National de la Recherche Agronomique, 37380 Nouzilly, France
}

(Received 29 April 1999 - Revised 22 October 1999 - Accepted 8 November 1999)

\begin{abstract}
The plasma glucose-insulin relationships and thyroid status were investigated in two lines of adult cockerels divergently selected for high $(\mathrm{R}+)$ or low $(\mathrm{R}-)$ residual food consumption (RFC). For a given body weight, $\mathrm{R}+$ birds had a $74 \%$ higher food intake than $\mathrm{R}-$ birds. Plasma glucose concentrations were significantly lower in the $\mathrm{R}+$ line compared with the $\mathrm{R}-$ when fasted, whereas $\mathrm{R}+$ birds exhibited a significantly lower plasma insulin concentration than $\mathrm{R}-$ birds either in fed or fasted state. After an overnight fast, $\mathrm{R}+$ birds also exhibited a higher sensitivity to exogenous insulin in view of its more pronounced hypoglycaemic effect. After an oral glucose load, the glucose disposal of $\mathrm{R}+$ cockerels was faster despite lower glucose-induced plasma insulin concentration. Whilst plasma triacylglycerol concentrations were lower in the $\mathrm{R}+$ line when fed, plasma non-esterified fatty acid concentrations were higher in fasted $\mathrm{R}+$ than $\mathrm{R}-$ cockerels $(684$ v. $522 \mu \mathrm{mol} / \mathrm{l})$. Higher plasma triiodothyronine concentrations were observed in fed $\mathrm{R}+$ compared with $\mathrm{R}$ - birds $(3 \cdot 0 \mathrm{v} \cdot 2 \cdot 1 \mathrm{nmol} / \mathrm{l}$ respectively). The higher plasma concentrations of triiodothyronine associated with lower concentrations of insulin could account for the leanness and the elevated diet-induced thermogenesis previously observed in the $\mathrm{R}+$ line.
\end{abstract}

Cockerels: Glucose-insulin relationships: Thyroid status: Hyperphagia

In animal production (meat, egg or milk production), twothirds of the total cost is accounted for by feed cost. Hence the improvement in feed efficiency (i.e. the reduction of food intake for a given level of production) has long been the main goal of breeders and geneticists of laying hens. An important part of the variation in food consumption is related to the body weight gain and the egg mass production (Fairfull \& Chambers, 1984). However, when these components are taken into account, a large difference between birds remains. This remaining part which is referred to as residual food consumption (RFC) may be used in selecting for food efficiency. Two experimental lines have thus been obtained by divergent selection exhibiting either high $(\mathrm{R}+)$ or low (R-) RFC (Zein-El-Dein et al. 1985; Bordas et al. 1992). In the adult period, the observed food intakes differ by $40 \%$ for males at the same body weight and by $30 \%$ for females of the same body weight and the same level of egg production. The BMR does not differ between the two lines (Geraert et al. 1991; Gabarrou \& Geraert, 1994a, b; Gabarrou et al. 1997a, $b, 1998)$. In contrast, in the fed state, $\mathrm{R}+$ birds exhibit enhanced heat production which is derived from enhanced diet-induced thermogenesis. This allows $\mathrm{R}+$ birds to dispose of their excessive energy intake. Only $25 \%$ of this extra dietary-induced thermogenesis could be accounted for by a higher physical activity in R+ birds (Gabarrou et al. 1997a). Therefore a difference between the two lines is likely to exist in the regulation of the thermogenic expenditure after food intake. Injection of propranolol (a $\beta_{2}$-adrenergic receptor blocker) reduced diet-induced thermogenesis only in $\mathrm{R}+$ chickens (Gabarrou et al. $1994 a, b)$ which suggests that the adrenergic system is partly involved in the divergence between these two lines.

Thyroid hormones have a major role in thermogenesis in birds as in mammals (May, 1989). Several components of thyroid control have been investigated in $\mathrm{R}+$ or $\mathrm{R}-$ chickens. Plasma triiodothyronine (T3) or thyroxine (T4) concentrations were measured in the fasted or the fed state (Gabarrou et al. 1997a, b). These measurements were not always done using a method adapted for birds' plasma and the results were not very different for each condition.

Surprisingly, $\mathrm{R}+$ birds which exhibit a higher food intake than $\mathrm{R}$ - birds in the adult period are also much leaner than R- birds (Zein-El-Dein et al. 1985; Tixier et al. 1988; El-Kazzi et al. 1995). In poultry diets, carbohydrates (mainly starch) are the main source of energy and they supply about $50 \%$ of the energy whilst the energy from dietary lipid is often less than $10 \%$. In birds, body lipids are mainly synthesized de novo from carbohydrates in the liver

\footnotetext{
Abbreviations: AUC, area under the curve; R+, high residual food consumption; R-, low residual food consumption; RFC, residual food consumption; T3, triiodothyronine; T4, thyroxine.

* Corresponding author: Dr Jean-François Gabarrou, present address ESA-PURPAN, 75 voie du TOEC, 31076 Toulouse Cedex, France, fax +330561 153060 , email gabarrou@esa-purpan.fr
} 
(Saadoun \& Leclercq, 1987). Increases in fattening are mainly due to the uptake by adipose tissue of triacylglycerol synthesized by the liver. In cafeteria-fed rats, Rothwell \& Stock (1981) previously observed a role for insulin in the diet-induced thermogenesis. The higher food intake and lower fatness of the $\mathrm{R}+$ line could thus be the result of changes in glucose utilization and/or insulin regulation. We presently investigated the glucose-insulin relationships in the two genotypes. In addition, plasma levels of T3, T4, non-esterified fatty acids, triacylglycerol, glucose and uric acid were determined in fasting or fed animals to further understand the metabolic changes induced by RFC selection.

\section{Materials and methods}

Animals and procedure

Sixty-six adult cockerels of the twenty-first generation of the R+ and R-types (Bordas et al. 1992) were reared in individual battery cages. They were individually fed on a complete standard diet containing $12.84 \mathrm{MJ}$ metabolizable energy and $126 \mathrm{~g}$ crude protein $/ \mathrm{kg}$. Ambient temperature was maintained at $20^{\circ}$. The lighting cycle was 09.00 to 23.00 hours light and 23.00 to 09.00 hours dark.

In cockerels, the RFC was determined between 32 and 36 weeks of age according to Bordas et al. (1992). Food intake was determined weekly and body weight was recorded after $16 \mathrm{~h}$ feed deprivation at the beginning of each experiment.

\section{Samples collection protocol}

Blood samples were collected from fed animals $5 \mathrm{~h}$ after the start of the light period and again after a $16 \mathrm{~h}$ fast (including a dark period). Plasma glucose, triacylglycerol, non-esterified fatty acids, uric acid, insulin and T3 and T4 concentrations were determined in twelve birds of each line under fed or fasting conditions.

\section{Sensitivity to exogenous insulin}

The test for sensitivity to exogenous insulin was performed in 52-week-old cockerels after $16 \mathrm{~h}$ fasting. Bovine insulin (Endopancrine 10 monopic, Organon, Paris, France) was diluted in sterile saline solution $(9 \mathrm{~g} \mathrm{NaCl} / \mathrm{l})$ and injected intramuscularly (gastrocnemius). Birds received either saline or $0.6,1.5$ or $3.0 \mu \mathrm{mol}$ insulin $/ \mathrm{kg}$ body weight (eight birds per treatment). Blood samples were taken 90 min after injection according to Simon \& Leclercq (1985).

\section{Oral glucose tolerance test}

Glucose tolerance was measured in 40-week-old cockerels of equal body weight after $16 \mathrm{~h}$ fasting using an oral glucose solution $(500 \mathrm{~g} / \mathrm{l})$ load $(2 \mathrm{~g} / \mathrm{kg}$ body weight $)$ introduced into the crop (Simon \& Leclercq, 1985). Blood was collected initially and at 10, 15, 30, 45, 60, 90 and 120 min after the glucose load from different birds at each time. The insulin secretion rate was estimated by measuring the area under the curve (AUC) after correction for baseline, relating the plasma insulin concentration following the glucose load from 0 to $120 \mathrm{~min}$.

\section{Treatment of blood samples}

All blood samples were taken from the wing vein using heparin as an anticoagulant. Samples were immediately chilled and plasma was separated by centrifugation $(1000 \mathrm{~g}$ for $15 \mathrm{~min})$. Portions of plasma were stored at $-20^{\circ}$ until analysis. Plasma insulin was measured by radioimmunoassay using a guinea-pig antiporcine insulin serum (Ab 27-6, a gift from G. Rosselin, Hospital Saint Antoine, Paris, France) and chicken insulin as standard as described by Rideau et al. (1986). Plasma glucose was determined with a glucose analyser (Beckman Instruments model 2, Palo Alto, CA, USA). Plasma triacylglycerol, uric acid and non-esterified fatty acids were measured by enzymic methods (Fossati et al. 1980; Okabe et al. 1980; Fossati \& Principe, 1982) using kits provided by BioMerieux SA (Charbonnières-les-Bains, France).

\section{Determination of plasma triiodothyronine and thyroxine concentrations}

Triiodothyronine and thyroxine radioimmunoassay. Sample or standard (50 $\mu \mathrm{l} ; 0 \cdot 31-10 \mathrm{nM}$ and $9 \cdot 4-300 \mathrm{nM}$ respectively for T3 and T4 assay) in $11 \times 55 \mathrm{~mm}$ polystyrene tubes were incubated with $50 \mu \mathrm{l}$ anti-T3 serum (initial dilution $1: 3000$; SAPU, Carluke, Scotland, UK), $50 \mu 1{ }^{125} \mathrm{I}-\mathrm{T} 3$ or ${ }^{125} \mathrm{I}-\mathrm{T} 4$ containing 2 (T3 assay) or 4 (T4 assay) mg anilynonaphathalene 8 sulfonate/ml (Netria, St. Bartholomew's Close, London, UK) and $50 \mu \mathrm{l}$ assay buffer (0.05 M-PBS with $1 \mathrm{~g} \mathrm{NaN}_{3} / 1 ; \mathrm{pH} 7.4$ ) for $30 \mathrm{~min}$ at $20^{\circ}$. Donkey antisheep serum $(50 \mu \mathrm{l} ; 1: 25$; SAPU) and normal sheep serum (50 $\mu \mathrm{l} ; 1: 200$; SAPU) were added and incubation was continued for a further $2 \mathrm{~h}$ at $20^{\circ}$. PEG $6000(1 \mathrm{ml}, 4 \mathrm{~g} / \mathrm{l})$ and Tween $20(1 \mathrm{ml}, 0 \cdot 1 \mathrm{~g} / \mathrm{l})$ were added and the mixture was left for $10 \mathrm{~min}$ at $20^{\circ}$ before centrifugation at $3000 \mathrm{~g}$ for $30 \mathrm{~min}$. The supernatant fraction was rejected and the tubes were counted for $1 \mathrm{~min}$ in a $\gamma$-spectrophotometer. Data reduction was performed using weighted four-variable logistic regression. Within-assay variation was 5.2 and $5.7 \%$ respectively for $\mathrm{T} 3$ and $\mathrm{T} 4$ assay and between-assay variation was 8.3 and $9.9 \%$ respectively for $\mathrm{T} 3$ and $\mathrm{T} 4$ assay.

Validation of triiodothyronine and thyroxine assays. A series of standard curves were prepared for plasma of domestic chickens (adult males, adult laying hens, juveniles of both sexes). The plasma was filtered on a $100 \times 200 \mathrm{~mm}$ column containing celite and charcoal $(1: 1, \mathrm{w} / \mathrm{w})$. Addition of ${ }^{125} \mathrm{I}-\mathrm{T} 3$ or ${ }^{125} \mathrm{I}-\mathrm{T} 4$ to plasma before filtration showed that this procedure removed $>97 \%$ of these hormones.

These standard curves were compared with a control standard curve prepared in assay buffer by simultaneous non-linear logistic regression (DeLean et al. 1978). For T3, the binding of the radiolabel at zero unlabelled ligand concentration $\left(\mathrm{B}_{0}\right)$ was approximately $10 \%$ lower and the slope was shallower when laying-hen plasma was used. The $\mathrm{ED}_{50}$ was similar for all plasma and significantly higher than that observed for the control curve $(1.09$ v. $0.7 \mathrm{nM} / \mathrm{l}$; $P=0 \cdot 012$ ). For T4, there was no significant difference in 
the $\mathrm{B}_{0}$, the non-specific binding nor in the slope of curves constituted in stripped plasma, except for laying hens, and the control curve. However, the $\mathrm{ED}_{50}$ was $2 \cdot 5$-fold less $(30$ v. $109 \mathrm{~nm} / \mathrm{l} ; P=0.025)$. The standard curve in laying-hen plasma showed significantly $(P=0.009)$ lower zero binding (2-fold less) and had a shallower slope (0.8 v. 1.01) than the other curves.

For routine assays, standard curves were performed using stripped plasma of cockerels.

\section{Statistical analysis}

Results are presented as means and standard errors of the means. Statistical analyses were performed by Student's $t$ test; $P<0.05$ was considered significant.

\section{Results}

The difference in food intake between the two lines was substantial, with $\mathrm{R}+$ birds consuming $74 \%$ more (129 v. $74 \mathrm{~g} / \mathrm{d}$ ) without any difference in body weight (3157 (SEM 58) v. 3094 (SEM 97) g respectively for $\mathrm{R}+$ and $\mathrm{R}$ - birds). This difference was even larger than the $40 \%$ increase previously reported by Bordas et al. (1992).

\section{Biological and endocrinological variables}

When birds had free access to food, no difference in plasma glucose (Table 1) was observed between lines. Feed deprivation significantly reduced plasma glucose in both lines, but to a greater extent in the $\mathrm{R}+$ line resulting in a slightly but significantly lower plasma glucose concentration after feed deprivation in the $\mathrm{R}+$ than in the $\mathrm{R}$ - line $(P<0 \cdot 05)$. In fed animals, triacylglycerol concentration was significantly lower in the $\mathrm{R}+$ line. Feed deprivation significantly decreased plasma triacylglycerol concentrations in both lines, but to a lower extent in the $\mathrm{R}+$ than in the $\mathrm{R}$ - line and no significant differences in plasma triacylglycerol concentrations between lines was observed in fasted birds. No differences between lines were observed for plasma non-esterified fatty acid concentrations in fed birds, but $\mathrm{R}+$ cockerels exhibited significantly higher plasma nonesterified fatty acid concentrations than $\mathrm{R}-$ when fasted. Similar results were observed for plasma uric acid concentrations: no difference between lines were observed when fed, but R+ cockerels exhibited a significantly higher plasma uric acid concentration than $\mathrm{R}$ - birds when fasted.

Plasma insulin concentration was significantly lower in $\mathrm{R}+$ cockerels either fed or fasted (Table 1). Plasma T3 concentration was significantly higher in fed cockerels of

Table 1. Plasma concentration of glucose, triacylglycerol, non-esterified fatty acids, uric acid, insulin, triiodothyronine (T3) and thyroxine (T4) concentrations in fed or fasted cockerels with high $(\mathrm{R}+)$ or low $(\mathrm{R}-)$ residual food consumption

(Mean values and standard errors of the mean for twelve cockerels)

\begin{tabular}{|c|c|c|c|c|c|}
\hline & \multicolumn{2}{|c|}{$\mathrm{R}+$} & \multicolumn{2}{|c|}{$\mathrm{R}-$} & \multirow{2}{*}{$\begin{array}{l}\text { Statistical } \\
\text { significance of } \\
\text { difference } \\
\text { between means } \\
\text { of } \mathrm{R}+\text { and } \mathrm{R}- \\
\text { lines: } P\end{array}$} \\
\hline & Mean & SEM & Mean & SEM & \\
\hline \multicolumn{6}{|c|}{ Plasma glucose $(\mathrm{mmol} / \mathrm{l})$} \\
\hline $\begin{array}{l}\text { Fed } \\
\text { Fasted (16h) }\end{array}$ & $\begin{array}{l}1.38 \\
1.22 \dagger\end{array}$ & $\begin{array}{l}0.02 \\
0.01\end{array}$ & $\begin{array}{l}1.39 \\
1.27 \dagger\end{array}$ & $\begin{array}{l}0.02 \\
0.02\end{array}$ & $\underset{*}{N S}$ \\
\hline \multicolumn{6}{|c|}{ Plasma triacylglycerol (mmol/l) } \\
\hline $\begin{array}{l}\text { Fed } \\
\text { Fasted (16h) }\end{array}$ & $\begin{array}{l}0.44 \\
0.27 \dagger\end{array}$ & $\begin{array}{l}0.05 \\
0.03\end{array}$ & $\begin{array}{l}0.69 \\
0.31 \dagger\end{array}$ & $\begin{array}{l}0.05 \\
0.06\end{array}$ & $\stackrel{*}{N S}$ \\
\hline \multicolumn{6}{|c|}{ Plasma non-esterified fatty acid ( $\mu \mathrm{mol} / \mathrm{l})$} \\
\hline $\begin{array}{l}\text { Fed } \\
\text { Fasted (16h) }\end{array}$ & $\begin{array}{l}291 \\
684 \dagger\end{array}$ & $\begin{array}{l}42 \\
41\end{array}$ & $\begin{array}{l}321 \\
531 \dagger\end{array}$ & $\begin{array}{l}39 \\
42\end{array}$ & $\underset{*}{N S}$ \\
\hline \multicolumn{6}{|c|}{ Plasma uric acid $(\mu \mathrm{mol} / \mathrm{l})$} \\
\hline $\begin{array}{l}\text { Fed } \\
\text { Fasted (16h) }\end{array}$ & $\begin{array}{l}458 \\
634 \dagger\end{array}$ & $\begin{array}{l}31 \\
31\end{array}$ & $\begin{array}{l}478 \\
522 \dagger\end{array}$ & $\begin{array}{l}46 \\
33\end{array}$ & $\underset{*}{N S}$ \\
\hline \multicolumn{6}{|c|}{ Plasma insulin (pmol/l) } \\
\hline $\begin{array}{l}\text { Fed } \\
\text { Fasted (16h) }\end{array}$ & $\begin{array}{c}121 \\
85 \dagger\end{array}$ & $\begin{array}{l}10 \\
10\end{array}$ & $\begin{array}{l}217 \\
144 \dagger\end{array}$ & $\begin{array}{l}22 \\
21\end{array}$ & $* *$ \\
\hline $\begin{array}{l}\text { Plasma T3 (nmol } \\
\text { Fed } \\
\text { Fasted (16h) }\end{array}$ & $\begin{array}{l}3.00 \\
1.55 \dagger\end{array}$ & $\begin{array}{l}0.26 \\
0.12\end{array}$ & $\begin{array}{l}2 \cdot 13 \\
1.73 \dagger\end{array}$ & $\begin{array}{l}0.15 \\
0.09\end{array}$ & NS \\
\hline $\begin{array}{l}\text { Plasma T4 (nmol } \\
\quad \text { Fed } \\
\text { Fasted }(16 \mathrm{~h})\end{array}$ & $\begin{array}{l}20 \cdot 8 \\
33 \cdot 1 \dagger\end{array}$ & $\begin{array}{l}1.5 \\
1 \cdot 1\end{array}$ & $\begin{array}{l}19 \cdot 6 \\
27 \cdot 8 \dagger\end{array}$ & $\begin{array}{l}1.8 \\
1.3\end{array}$ & $\underset{* *}{N S}$ \\
\hline $\begin{array}{l}\text { Plasma T3: T4 re } \\
\text { Fed } \\
\text { Fasted }(16 \mathrm{~h})\end{array}$ & $\begin{array}{l}0.157 \\
0.048 \dagger\end{array}$ & $\begin{array}{l}0.018 \\
0.004\end{array}$ & $\begin{array}{l}0.130 \\
0.065 \dagger\end{array}$ & $\begin{array}{l}0.026 \\
0.005\end{array}$ & $\underset{*}{N S}$ \\
\hline
\end{tabular}

${ }^{\star} P<0.05,{ }^{* \star} P<0.01$.

Mean values were significantly different from those in the fed state: $† P<0.01$. 
the $\mathrm{R}+$ line. $\mathrm{T} 3$ concentrations did not significantly differ between feed-deprived $\mathrm{R}+$ and $\mathrm{R}-$ cockerels. No significant difference in plasma T4 concentrations between lines was observed in fed animals, but the T4 concentration was significantly higher in the $\mathrm{R}+$ than in the $\mathrm{R}-$ line when fasted $(P<0.01)$.

\section{Sensitivity to exogenous insulin}

The sensitivity to exogenous insulin measured in birds fasted overnight is shown in Fig. 1. In this present experiment, no difference between lines in plasma glucose was observed during feed deprivation. Over a dose range of 0.6 to $3.0 \mu \mathrm{mol} / \mathrm{kg}$, insulin decreased plasma glucose in both lines in a dose-related manner. No difference between lines was observed at the dose of $0.6 \mu \mathrm{g} / \mathrm{kg}$, but at the doses of 1.5 and $3.0 \mu \mathrm{mol} / \mathrm{kg}$, plasma glucose was significantly lower in the $\mathrm{R}+$ than in the $\mathrm{R}-$ line.

\section{Oral glucose tolerance test}

The results of the oral glucose tolerance test are shown in Fig. 2. No significant difference in plasma glucose was observed between lines when fasting. Plasma glucose markedly increased $10 \mathrm{~min}$ after glucose ingestion in both lines and reached a maximum value about 5 min later. From 15-45 min after loading, $\mathrm{R}+$ exhibited significantly higher plasma glucose than R-cockerels (except at 30 min where $P$ was only $0 \cdot 1$ ). At $60 \mathrm{~min}$, no difference was detected, but subsequently, between 90 and 120 min after loading, plasma glucose was significantly lower in the $\mathrm{R}+$ line. At these last two time points, plasma glucose had returned to the initial fasted value in the $\mathrm{R}+$ birds but remained significantly higher than the initial value in the $\mathrm{R}$ - birds.

The plasma insulin concentration was significantly lower in the $\mathrm{R}+$ than in the $\mathrm{R}$ - line when fasting (Fig. 2(b)). Plasma insulin increased after the glucose load in both lines and peaked at $10 \mathrm{~min}$. From $10-120 \mathrm{~min}, \mathrm{R}+$ cockerels exhibited consistently lower plasma insulin concentration; only the value at $60 \mathrm{~min}$ failed to attain statistical significance $(P<0 \cdot 1)$.

The area under the insulin curve was significantly lower from $0-15 \mathrm{~min}$ in the $\mathrm{R}+$ line $(1.08 v .1 .35 \mathrm{nmol} / 1, P<0.05)$ and thereafter did not significantly differ up to $120 \mathrm{~min}$.

\section{Discussion}

Some aspects of the glucose-insulin relationship are specific to birds: basal plasma glucose level is about 2-3fold higher than in mammals whereas basal plasma insulin concentration is very similar to that observed in most fasting mammals (Simon, 1989). The difference that is observed between lines (Table 1) for the glucose-insulin relationship suggests that selection on RFC has been associated with changes in the pancreatic reactivity to glucose and/or the insulin sensitivity of liver and/or peripheral tissues.

In both lines, plasma insulin increased in response to an oral glucose load but insulin levels remained significantly lower in the $\mathrm{R}+$ as compared with the $\mathrm{R}-$ line during the oral glucose tolerance test. Initially $(0-15 \mathrm{~min})$, the area under the insulin curve was reduced in $\mathrm{R}+$ compared with $\mathrm{R}-$ birds. From 15-45 min following the glucose load, blood glucose was higher in the $\mathrm{R}+$ line cockerels possibly as a result of the lower plasma insulin concentrations between 0 and $15 \mathrm{~min}$. This suggests that the $\beta$-cell sensitivity to glucose may be slightly reduced in $\mathrm{R}+$ compared with $\mathrm{R}-$ lines which is also suggested by the low levels of insulin observed in fed or fasted chickens. After the glucose load, plasma glucose returned to the basal level within $90 \mathrm{~min}$ in the $\mathrm{R}+$ group, showing no delay in the clearance of glucose. Plasma glucose decreased less abruptly in the $\mathrm{R}$ - cockerels despite much higher plasma insulin throughout the time course suggesting a state of insulin resistance in this genotype. Accordingly, the $\mathrm{R}+$ line was significantly more sensitive than the $\mathrm{R}$ - line to the high concentration of exogenous insulin in view of the hypoglycaemic effect. The sensitivity to exogenous insulin was assessed 12 weeks after the oral glucose tolerance test. However, as the same

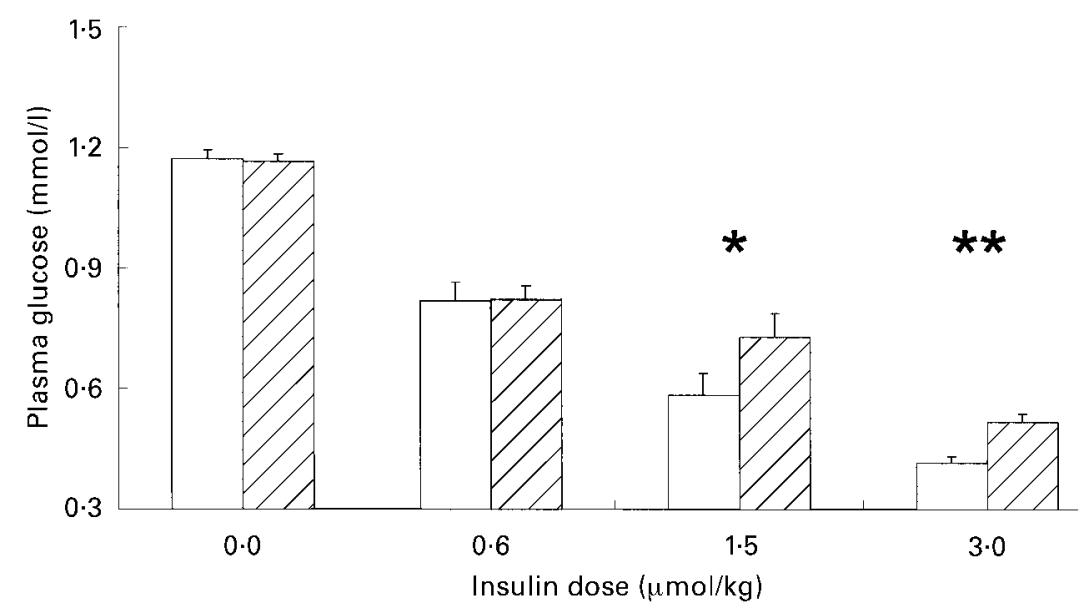

Fig. 1. Sensitivity of fasted cockerels to exogenous insulin. Plasma glucose was measured $90 \mathrm{~min}$ after intramuscular injection of saline (control) or insulin. ( $\square$ ), Cockerels with high residual food consumption $(R+)$; $(\mathbb{Q})$, cockerels with low residual food consumption (R-). Values are means for eight cockerels per line with standard errors of the mean shown by vertical bars. ${ }^{\star} P<0.05$, ${ }^{\star *} P<0.01$ (Student's $t$ test). 

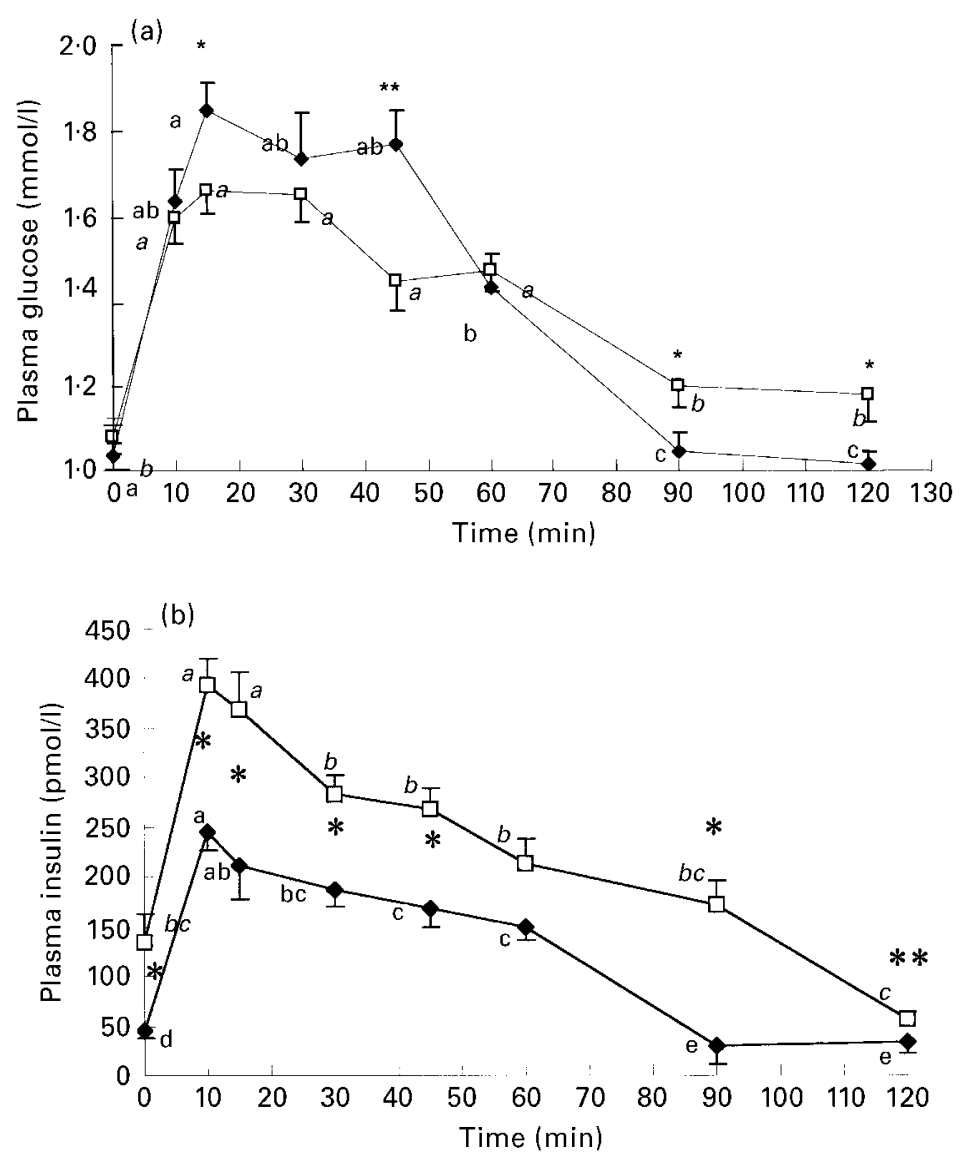

Fig. 2. In vivo glucose tolerance measured by (a) plasma glucose concentration and (b) plasma insulin concentration in fasted cockerels. $(-)$, Cockerels with high residual food consumption $(\mathrm{R}+)$; $(-\square-)$, cockerels with low residual food consumption (R-). Values are means for eight cockerels per line with standard errors of the mean shown by vertical bars. Mean values were significantly different: ${ }^{*} P<0.05$, ${ }^{* \star} P<$ 0.01 (Student's $t$ test). Significance of the time course for each line: values followed by values with the same letter are not significantly different (any point with at least one letter in common with another point is not significantly different from this point), $P<0.05$ (Tukey test).

animals were used for the two tests, 12 weeks are enough to consider that there were no more interactions between the two treatments. On the other hand, the risk of this method is to compare results without taking into account the effect of age. In fact, as only adults cockerels were used, it is possible to consider that the effect of age was very little. Moreover, the difference in RFC was controlled during all the period of experimentation suggesting no modification in the metabolism of these birds during the period of control.

Present results concerning plasma T3 and T4 confirmed previous ones (Gabarrou et al. 1997a, b, 1998) i.e. T3 was higher in $\mathrm{R}+$ cockerels. However, no significant differences were presently observed for $\mathrm{T} 3$ in the fasted state and in contrast T4 was significantly higher in fed $\mathrm{R}+$ cockerels. Previously no changes were found for T4, but the assay was done with a method developed for human T4. In the fed state, low plasma T3 levels associated with high plasma insulin levels, such as those found in R- birds, would reduce thermogenesis expenditure and stimulate lipogenesis respectively. This fits with the plasma triacylglycerol concentration that was also higher in fed $\mathrm{R}$ - birds. Furthermore, there is a suggestion that in man, in the post-absorptive state, insulin decreases the thermic effect of adrenaline (Müller et al. 1992). This may, however, have to be revisited in view of the recent findings concerning the control of energy expenditure (see later). The endocrine environment found in R- cockerels would lead them to store more fat. The reverse situation prevails in fed $\mathrm{R}+$ cockerels (high T3 and low insulin levels). This endocrine balance, associated with enhanced physical activity would lead them to dissipate more energy and store less fat, despite their comparatively high food intake.

Results from glucose tolerance and insulin injection experiments suggest that $\mathrm{R}+$ cockerels behave as hyperthyroidic animals and $\mathrm{R}-$ cockerels as hypothyroidic ones. In chickens, experimental hyperthyroidism (induced by dietary T3 supplementation or hypothyroidism (induced by dietary propythiouracil supplementation) improves or impairs glucose tolerance respectively (Raheja et al. 1980; 
Buyse et al. 1990). In man, the most important feature of hypothyroidism is the increase in body fat mass which occurs even during mild hypothyroidism (Wolf et al. 1996; Seppel et al. 1997). Recently, an interaction between insulin and thyroid hormones has been observed at the level of the proteolitic pathway in various tissues. In fact, insulin sensitivity is reduced in hypothyroidic patients (Rochon et al. 2000) whereas it is increased during experimental hyperthyroidism in healthy subjects (Tauveron et al. 1995). Further investigations on protein metabolism in R+ and Rchicken are clearly awaited.

It is noteworthy that in chickens, fattening is not consistently associated with insulin resistance: surprisingly, genetically fat chickens are in fact more sensitive to exogenous insulin in a feed-deprivation state when considering the hypoglycaemic response than their genetically lean counterparts (Saadoun et al. 1987; Rideau, 1988).

As a whole, multiple differences appear to be present in the experimental $\mathrm{R}+$ and $\mathrm{R}-$ chicken model for several interacting endocrine systems: insulin system (possibly at the $\beta$-cell level and certainly at the level of peripheral tissues, present studies), thyroid system (present and previous (Gabarrou et al. 1997b) studies) and adrenergic system (propranolol was previously shown to decrease diet-induced thermogenesis (Gabarrou et al. 1994a,b) in $\mathrm{R}+$ cockerels only). Further pieces of information have to be added to this 'puzzle' before the driving system(s) which governs energy expenditure and energy storage can be identified precisely in $\mathrm{R}+, \mathrm{R}$ - cockerels. In mammals, this new field is developing very fast. Briefly, leptin (a hormone released by adipocytes under the control of multiple hormones, including insulin) is known to interact at the level of the hypothalamus (and most likely in several peripheral tissues), to decrease food intake and stimulate energy expenditure (Houseknecht, 1998). Specific uncoupling proteins (at the moment at least three uncoupling proteins have been identified) are present in different tissues and permit heat production and energy dissipation (Ricquier \& Bouillaud, 1998). To our knowledge, uncoupling proteins have not yet been identified in chickens. Recently, chicken cDNA coding for leptin has been cloned and sequenced (Taouis et al. 1998). Surprisingly, in chickens, leptin is abundantly expressed in liver. The physiological consequences of this peculiarity is presently unknown. The $\mathrm{R}+$, $\mathrm{R}$ - model is potentially of great interest to explore the functions of uncoupled proteins and their regulation by leptin and the other hormones. The development of new experimental tools is clearly a prerequisite.

\section{Acknowledgements}

This study was funded by a grant from the 'Region Centre'. The authors are grateful to J. D. Terlot for his care of the animals, to S. Guillaumin and S. Crochet for their technical assistance and to J. Simon for his help in editing of the manuscript.

\section{References}

Bordas A, Tixier-Boichard M \& Mérat P (1992) Direct and correlated responses to divergent selection for residual food intake in Rhode Island Red laying hens. British Poultry Science 33, 741-754.

Buyse J, Decuypere E \& Simon J (1990) The effect of thyroid hormone status on plasma glucose-insulin interrelationship in broiler chickens. Reproduction Nutrition and Development 30 , 683-692.

DeLean A, Munson PJ \& Rodbard D (1978) Simultaneous analysis of families of sigmoidal curves; application to bioassay, radioligand assay, and physiological dose-response curves. American Journal of Physiology 235, E97-E102.

El-Kazzi M, Bordas A, Gandemer G \& Minvielle F (1995) Divergent selection for residual food intake in Rhode Island Red egg-laying lines: gross carcase composition, carcass adiposity and lipid contents of tissues. British Poultry Science 36, 719-728.

Fairfull RW \& Chambers JR (1984) Breeding for feed efficiency: poultry. Canadian Journal of Animal Science 64, 513-527.

Fossati P \& Prencipe L (1982) Serum triglycerides determined colorimetrically with an enzyme that produces hydrogen peroxide. Clinical Chemistry 28, 2077-2080.

Fossati P, Prencipe L \& Berti G (1980) Use of 3,5-dichloro-2hydroxybenzenesulfonic acid/4-aminophenazone chromogenic system in direct enzymatic assay of uric acid in serum and urine. Clinical Chemistry 26, 227-231.

Gabarrou JF \& Geraert PA (1994a) $\beta$-adrenergic and serotoninergic control of diet-induced thermogenesis in birds. Reproduction Nutrition Development 34, 634.

Gabarrou JF \& Geraert PA (1994b) Regulation of diet-induced thermogenesis. In Proceedings of the 13th Symposium of Energy Metabolism of Farm Animals. European Association for Animal Production Publication no. 76, pp.113-116. Mojacar, Spain: EAAP.

Gabarrou JF, Géraert PA, Picard M \& Bordas A (1997a) Dietinduced thermogenesis in cockerels is modulated by genetic selection for high or low residual feed intake. Journal of Nutrition 127, 2371-2376.

Gabarrou JF, Duchamp C, Williams J \& Géraert PA (1997b) A role for thyroid hormones in the regulation of diet-induced thermogenesis in birds. British Journal of Nutrition 78, 963-973.

Gabarrou JF, Géraert PA, François N, Guillaumin S, Picard M \& Bordas A (1998) Energy balance of laying hens selected on residual food consumption. British Poultry Science 39, 79-89.

Geraert PA, Guillaumin S, Bordas A \& Mérat P (1991) Evidence of a genetic control of diet-induced thermogenesis in poultry. In Proceedings of the 13th Symposium of Energy Metabolism of Farm Animals. European Association for Animal Production Publication no. 58, pp.380-383. Kartause Ittinen, Switzerland: EAAP.

Houseknecht KL \& Portocarrero CP (1998) Leptin and its receptor: regulation of whole body energy homeostasis. Domestic Animal Endocrinology 15, 457-475.

May JD (1989) The role of the thyroid in avian species. Critical Review of Poultry Biology 2, 171-186.

Müller MJ, Acheson KJ, Piolol V, Jeanpretre N, Burger AG \& Jequier E (1992) Thermic effect of epinephrine: a role for endogenous insulin. Metabolism 41, 582-587.

Okabe H, Uji Y, Nagashima K \& Noma A (1980) Enzymatic determination of free fatty acids in serum. Clinical Chemistry 26, 1540-1543.

Raheja KL, Linscheer WG, Coulson R, Wenthworth S \& Pineberg SE (1980) Elevated insulin-glucagon ratios and decreased cyclic AMP levels accompany the glycogen and triglyceride storage syndrome in the hypothyroid chick. Hormone and Metabolic Research 12, 51-55.

Ricquier D \& Bouillaud F (1998) Les proteines découplantes mitochondriales (Mitochondrial uncoupling proteins). Medecine Science 14, 889-897. 
Rideau N (1988) Insulin secretion in birds. In Leaness in Domestic Birds, pp. 269-294 [B Leclercq and CC Whitehead, editors]. London: Butterworths.

Rideau N, Simon J \& Leclercq B (1986) Further characterisation of insulin secretion from the perfused duodenum-pancreas of chicken: a comparison of insulin release in chickens selected for high and low abdominal fat content. Endocrinology 119 $2635-2640$.

Rochon C, Tauveron I, Dejax C, Benoit P, Capitan P, Bayle G, Prugnaud J, Fabricio A, Berry C, Champredon C, Thieblot P \& Grizard J (2000) Response of leucine metabolism to hyperinsulinemia in hypothyroid patients before and after thyroxine replacement. Journal of Clinical Endocrinology and Metabolism 85, 697-706.

Rothwell NJ \& Stock MJ (1981) A role for insulin in the dietinduced thermogenesis of cafeteria-fed rats. Metabolism 30, 673-678.

Saadoun A \& Leclercq B (1987) In vivo lipogenesis in genetically fat and lean chickens: effects of nutritional state and dietary fat. Journal of Nutrition 117, 428-435.

Seppel T, Kosel A \& Schlaghecke R (1997) Bioelectrical impedance assessment of body composition in thyroid disease. European Journal of Endocrinology 136, 493-498.

Simon J \& Leclercq B (1985) Fat and lean chickens: prefattening period and in vivo sensitivity to insulin, atropine, and propranolol. American Journal of Physiology 249, R393-R401.

Taouis M, Chen JW, Daviaud C, Dupond J, Derouet M \& Simon J (1998) Cloning the chicken lectin gene. Gene 208, 239-242.

Tauveron I, Charrier S, Champredon C, Bonnet Y, Berry C, Bayle G, Prugnaud J, Obled C, Grizard J \& Thieblot P (1995) Response of leucine metabolism to hyperinsulinemia under amino acid replacement in experimental hyperthyroidism. American Journal of Physiology 269, E499-E507.

Tixier M, Bordas A \& Mérat P (1988) Divergent selection for residual feed intake in laying hens: effect on growth and fatness. In Leaness in Domestic Birds, pp. 129-132 [B Leclercq and CC Whitehead, editors]. London: Butterworths.

Wolf M, Weigert A \& Kreymann G (1996) Body composition and energy expenditure in thyroidectomized patients during shortterm hypothyroidism and thytropin-suppressive thyroxine therapy. European Journal of Endocrinology 134, 168-173.

Zein-El-Dein A, Bordas A \& Merat P (1985) Selection divergente pour la composante résiduelle de la consommation alimentaire des poules pondeuses: effets sur la composition corporelle (Divergent selection for residual food consumption in laying hens: effect on body composition). Archiv für Geflügelkünde $\mathbf{4 9}$, $158-160$ 